BRITISH POLITICS SINCE THE WAR 
Also by Bill Coxall and Lynton Robins

CONTEMPORARY BRITISH POLITICS 


\section{British Politics since the War}

Bill Coxall

and

Lynton Robins

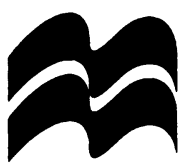




\section{MACMILLAN PRESS LTD}

Houndmills, Basingstoke, Hampshire RG21 6XS and London

Companies and representatives throughout the world

A catalogue record for this book is available from the British Library.

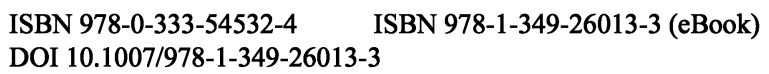

First published in the United States of America 1998 by

ST. MARTIN'S PRESS, INC.,

Scholarly and Reference Division,

175 Fifth Avenue, New York, N.Y. 10010

ISBN 978-0-312-21108-0

Library of Congress Cataloging-in-Publication Data

Coxall, W. N.

British politics since the war / Bill Coxall \& Lynton Robins.

p. $\mathbf{c m}$.

Includes bibliographical references ( $p . \quad$ ) and index.

ISBN 978-0-312-21108-0

1. Great Britain-Politics and government-1945- 2. World War,

1939-1945-Influence. I. Robins, L. J. (Lynton J.) II. Title.

DA589.7.C69 1997

$941.085-\mathrm{dc} 21$

97-35661

CIP

(c) Bill Coxall and Lynton Robins 1998

All rights reserved. No reproduction, copy or transmission of this publication may be made without written permission.

No paragraph of this publication may be reproduced, copied or transmitted save with written permission or in accordance with the provisions of the Copyright, Designs and Patents Act 1988, or under the terms of any licence permitting limited copying issued by the Copyright Licensing Agency, 90 Tottenham Court Road, London WIP 9HE.

Any person who does any unauthorised act in relation to this publication may be liable to criminal prosecution and civil claims for damages.

The authors have asserted their rights to be identified as the authors of this work in accordance with the Copyright, Designs and Patents Act 1988.

This book is printed on paper suitable for recycling and made from fully managed and sustained forest sources.

$\begin{array}{llllllllll}10 & 9 & 8 & 7 & 6 & 5 & 4 & 3 & 2 & 1\end{array}$

$\begin{array}{llllllllll}07 & 06 & 05 & 04 & 03 & 02 & 01 & 00 & 99 & 98\end{array}$ 


\section{Contents}

List of Figures viii

List of Tables ix

List of Exhibits $\quad \mathrm{x}$

List of Photographs xi

Preface xii

Acknowledgements xiii

$\begin{array}{ll}\text { Introduction: Britain in } 1945 & 1\end{array}$

The party system 1

The expansion of government 5

$\begin{array}{lr}\text { Social class, culture and politics } & 10\end{array}$

International role 11

The impact of the Second World War 14

1 The Governments of Postwar Britain 17

The Labour governments, 1945-51 17

The Conservative governments, 1951-64 22

The Labour governments, 1964-70 27

The Conservative government, 1970-4 32

The Labour governments, 1974-9 36

The Conservative governments, 1979-97 40

2 The Rise and Fall of Consensus Politics 49

The postwar consensus $\quad 49$

The breakdown of consensus, 1979 to the 1990s 60

The 1990s: towards a new consensus? 65

3 Society, Economy and Politics 69

Social and economic change, 1945-95 69

$\begin{array}{ll}\text { Political elites } & 76\end{array}$

Political participation $\quad 84$

$\begin{array}{ll}\text { The mass media } & 86\end{array}$ 
4 The Territorial Dimension $\quad 92$

$\begin{array}{ll}\text { Britain as a multinational state } & 92\end{array}$

The nations of multinational Britain $\quad 93$

Party politics on the UK periphery $\quad 95$

Governing the United Kingdom $\quad 99$

Nationalism and devolution in Scotland and Wales 101

Northern Ireland, 1945-72 106

Northern Ireland, 1972 to the 1990s 110

Scottish and Welsh nationalism in the 1980s and 1990s 113

5 Britain and Europe $\quad 116$

$\begin{array}{ll}\text { The Schuman Plan } & 117\end{array}$

$\begin{array}{ll}\text { The Pleven Plan } & 119\end{array}$

$\begin{array}{lr}\text { The Treaty of Rome } & 120\end{array}$

$\begin{array}{ll}\text { The British position } & 121\end{array}$

$\begin{array}{ll}\text { Britain's changing policy } & 122\end{array}$

$\begin{array}{ll}\text { Britain's second EEC application } & 124\end{array}$

Britain's entry to the EEC and Labour's response 126

Thatcherism, Conservatism and Europeanism 130

The impact of Britain's membership of the EEC 133

$\begin{array}{ll}\text { Maastricht and beyond } & 134\end{array}$

$\begin{array}{ll}\text { Britain and Europe } & 136\end{array}$

6 The Constitution 138

1945 to the early 1960 s: relative commitment, limited debate $\begin{array}{ll}\text { and modest change } & 138\end{array}$

Early 1960s to 1975: growing doubts and the drive to modernise British institutions

1975 to the present: radical discontent and the written constitution debate

7 The Political Parties 164

The Conservative Party 164

The Labour Party 176

The Liberal Party (1945-88) 188

$\begin{array}{ll}\text { The Social Democratic Party } & 190\end{array}$

The Liberal Democrats 191

The Green Party 191

$\begin{array}{ll}\text { The far left } & 192\end{array}$

$\begin{array}{ll}\text { The extreme right } & 193\end{array}$ 
8 Voters and Elections 195

$\begin{array}{ll}\text { Britain's changing party system } & 195\end{array}$

Voting behaviour in postwar Britain $\quad 202$

Key general elections: 1945 and 1979

9 Managing Britain's Economy 213

$\begin{array}{ll}\text { The era of state intervention } & 215\end{array}$

$\begin{array}{ll}\text { The era of retreat } & 229\end{array}$

$\begin{array}{ll}\text { The impact of change } & 235\end{array}$

10 Social Policy and the Welfare State 237

$\begin{array}{ll}\text { Did Britain get a welfare state? } & 238\end{array}$

The Liberal inheritance: Keynes and Beveridge 241

$\begin{array}{ll}\text { Constructing the welfare state } & 242\end{array}$

$\begin{array}{ll}\text { The retreat from welfare } & 249\end{array}$

11 Foreign and Defence Policies 257

The basis of Britain's foreign and defence policies $\quad 257$

$\begin{array}{ll}\text { Great-power Britain } & 259\end{array}$

$\begin{array}{ll}\text { The special relationship } & 272\end{array}$

$\begin{array}{ll}\text { The European context } & 277\end{array}$

$\begin{array}{ll}\text { Britain's changing role } & 278\end{array}$

12 Ideological Perspectives on Postwar British Politics 280

$\begin{array}{ll}\text { The Marxist left } & 281\end{array}$

$\begin{array}{ll}\text { The new right } & 287\end{array}$

$\begin{array}{ll}\text { The political centre } & 294\end{array}$

$\begin{array}{ll}\text { Bibliography } & 305\end{array}$

$\begin{array}{ll}\text { Index } & 316\end{array}$ 


\section{List of Figures}

2.1 Welfare spending, 1951-88 54

2.2 Housing tenure, $1945-89$

2.3 Public spending as a proportion of GDP, 1970-90 61

3.1 Changes in the workforce, 1951-92 71

3.2 The growth of the British economy, 1951-92 71

3.3 Trade union membership, 1945-97 74

3.4 The educational background of MPs in the two main parties, 1951-92 76

3.5 The social background of MPs in the two main parties, 1918-92 77

5.1 The changing pattern of Britain's foreign trade 125

8.1 Class-based voting in general elections, 1959-79 203

9.1 Comparative economic growth rates, 1938-64 213

9.2 The stop-go cycle 217

10.1 House building in England and Wales, 1945-93 245

11.1 The retreat from empire, 1947-80: Africa 264

11.2 The retreat from empire, 1947-80: the Far East and the West Indies

11.3 Defence cuts, 1975-95 


\section{List of Tables}

I.1 Governments between 1918 and 1945

2.1 Incomes policy, 1961-77 52

2.2 From the mixed to the privatised economy, 1945-95 62

3.1 Percentage of age group in full-time education, 1938-90 72

3.2 Women in the labour force, 1951-91 73

3.3 Unemployment, 1965-92 74

3.4 Women MPs, 1945-92 78

3.5 Ethnic minority MPs, 1970-97 79

3.6 The social and educational background of cabinet ministers,
1916-84

4.1 The leading mainland parties and the Scottish National Party in general elections in Scotland, 1945-97 96

4.2 The leading mainland parties and Plaid Cymru in general elections in Wales, 1945-97 97

4.3 General elections in Northern Ireland, 1974-97 98

4.4 The devolution referendums, $1979 \quad 106$

7.1 The political parties: total votes, share of votes and seats, 1945-97

7.2 Conservative leadership contests, 1965-95 170

7.3 Progressive and Thatcherite conservatism 175

$\begin{array}{ll}\text { 7.4 Labour leadership contests, } 1955-80 & 180\end{array}$

7.5 Labour leadership contests under the electoral college, 1981-94

8.1 Two party support and domination, 1945-97 196

8.2 Voting by social class, $1945-58 \quad 203$

8.3 Gender and party choice in general elections, 1964-97 206

9.1 Inflation, unemployment and industrial action, 1970-94 219

9.2 Britain's balance of payments, 1964-9 223

9.3 The economic record of postwar governments, 1951-88 235 


\section{List of Exhibits}

I.1 The growth of state welfare, 1870-1940 7

2.1 Consensus and new consensus $\quad 67$

3.1 Pressure groups and social movements 87

5.1 Continental and British mindsets 118

5.2 Socialist fears about loss of British sovereignty 129

6.1 The constitution and political institutions: main changes, 1945 to the 1960s 143

6.2 The constitution and political institutions: main changes, 1960s to 1975

6.3 The Fulton Report on the Civil Service (1968): recommendations and implementation

6.4 The constitution and political institutions: main changes, 1975 to the 1990s 155

7.1 Rules for the election of the Conservative leader from $1965 \quad 168$

8.1 The break-up of the coalition 209

9.1 The statement of intent 226

10.1 The welfare state in transition 240

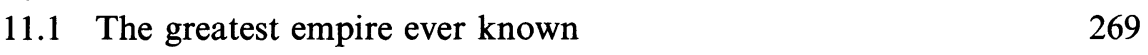

12.1 New left perspectives on postwar history 286

12.2 The right-wing assault on the postwar settlement: the attack on Keynesianism 288

12.3 The traditional new right: the need to restore moral authority 292

12.4 The adversary politics thesis 295

12.5 The class politics thesis 296

12.6 The lack of a developmental state in Britain 299 


\section{List of Photographs}

The Attlee Cabinet (1945) 18

The Churchill Cabinet (1955) 24

The Macmillan Cabinet (1963) 25

The Wilson Cabinet (July 1965) 28

The Heath Cabinet (1970) 34

The Callaghan Cabinet (1976) 38

The Thatcher Cabinet (1988) 43

The Major Cabinet (1992) $\quad 43$

$\begin{array}{ll}\text { The Blair cabinet (1997) } & 47\end{array}$

Liverpool dockers $\quad 72$

The era of state intervention: John Maynard Keynes at the UN

Monetary and Financial Conference, $1944 \quad 216$

William Beveridge $\quad 242$ 


\section{Preface}

Recent history - the period covering their own and their parents' lives - is often the period about which students know least, and the authors have long been aware that, despite the existence of some excellent works of contemporary history of a more advanced kind, no satisfactory introduction to the subject has been available. This book is an attempt to fill that gap.

After a scene-setting survey of prewar and wartime Britain, the book opens with a straightforward account of post-Second World War British governments from Attlee to Major, focusing on the main electoral and national developments and events. For the most part it then proceeds thematically, combining discussions of developments in political ideas, institutions and behaviour (Chapters 4-8) with the treatment of specific policy areas (Chapters 9-11). The remaining chapters offer broad overviews. Thus Chapter 2 examines postwar British politics from the perspective of consensus, its breakdown and possible reemergence, Chapter 3 considers some important political consequences of social change, and Chapter 12 looks at the history of Britain since 1945 from the viewpoint of the main political ideologies.

As with Contemporary British Politics, for which it provides, if we may use the term, a 'prequel', the authors hope that the book will prove useful not only to A level and first-year university students but also to everyone with an interest in recent British political history.

We take this opportunity to express our thanks to our publisher Steven Kennedy for his encouragement and advice and to Houri Alavi (also of Macmillan) for her editorial assistance. 


\section{Acknowledgements}

The authors and publishers wish to thank the following for permission to use copyright material:

Guardian News Service Ltd for Table 9.3 from The Guardian, 26.4.89;

Oxford University Press for Table 3.9 from M. Burch and M. Moran, 'The Changing British Political Elite, 1945-83: MPs and Cabinet Ministers', Parliamentary Affairs, 38 (1985);

Talking Politics, Journal of The Politics Association, for an extract from Ian Holliday, 'The Welfare State 1979-93: Safe in Conservative Hands?' Talking Politics, 6: 2 (1994) pp. 82-94;

Central Office of Information, London, for photographs on pages 24, 34, 38, 43 and 47.

Centre for the Study of Cartoons and Caricature, University of Kent, Canterbury, for cartoons on pages 55, 123, 168, 210, 244 and 268, all copyright John Appleton, Solo Syndication Limited, London.

Colin Jones, copyright The Observer for photograph on page 72 .

Hulton Images for photograph on page 216.

National Museum of Labour History for photographs on pages 18, 28 and 242 .

Oxford University Press for maps on pages 264-5 from The Oxford History of Britain: The Modern Age, 1992, ed. by H.C.G. Matthew and K.O. Morgan.

Every effort has been made to trace all the copyright holders, but if any have been inadvertently overlooked the publishers will be pleased to make the necessary arrangement at the first opportunity. 
This book is dedicated to Stephen, Matthew, Edward, Jonathan, Anne and Stephen 